\title{
PENGARUH DIMENSI KOMUNIKASI INTERPERSONAL TERHADAP KEPUASAN KONSUMEN (KASUS DI KEDAI KOPI ARMOR, TAMAN HUTAN RAYA DJUANDA, BANDUNG)
}

\author{
Raihan Prasetyo $^{\left.1^{*}\right)}$, Rani Andriani Budi Kusumo ${ }^{2)}$ \\ 1) Alumni Program Studi Agribisnis Universitas Padjadjaran \\ ${ }^{2)}$ Staf Pengajar Program Studi Agribisnis Universitas Padjadjaran \\ Email: raihan_rg@yahoo.com
}

\begin{abstract}
ABSTRAK
Persaingan pasar yang ketat menuntut Kedai Kopi Armor untuk menyusun strategi pemasaran agar dapat menciptakan konsumen dan tentunya eksistensi perusahaan. Komunikasi interpersonal merupakan salah satu faktor yang dapat menciptakan kepuasan konsumen. Tujuan penelitian ini untuk menganalisis pengaruh kualitas komunikasi interpersonal yang terjalin antara karyawan (barista) dan konsumen terhadap tingkat kepuasan konsumen. Penelitian dilakukan di Kedai Kopi Armor Bandung. Penelitian ini merupakan penelitian kuantitatif dengan teknik survei. Responden dalam penelitian ini berjumlah 94 orang yang diambil dengan teknik acak sederhana. Data dianalisis melalui analisis regresi linier berganda. Hasil penelitian menunjukan bahwa kedai kopi armor menerapkan edukasi langsung dari barista ke konsumen melalui komunikasi interpersonal yang membentuk kepuasan konsumen. Hasil uji regresi menunjukkan secara parsial diketahui bahwa variabel keterbukaan, sikap positif, dan sikap mendukung berpengaruh signifikan terhadap kepuasan konsumen, sementara itu variabel empati dan kesetaraan tidak menunjukkan pengaruh yang signifikan terhadap kepuasan pelanggan. Secara simultan terdapat pengaruh signifikan antara komunikasi interpersonal dengan kepuasan konsumen. Karyawan sebagai ujung tombak sebuah perusahaan hendaknya mampu berkomunikasi secara tepat kepada konsumen untuk meningkatkan kepuasan konsumen.
\end{abstract}

Kata kunci: pengaruh, komunikasi, interpersonal, kepuasan, konsumen

\begin{abstract}
Intense market competition requires Café Armor to develop strategies in order to retain customers and the existence of the company. One of the factors that could affect customer satisfaction is interpersonal communication. This study aims to analyze the influence of interpersonal communication between barista and consumers to the level of customer satisfaction. The study was conducted at Café Armor Bandung. This research is a quantitative research with survey techniques. Respondents in this study amounted to 94 people taken by simple random sampling. Data were analyzed by multiple linier regression analysis. The result showed that Café Armor gave education and information to their consumers through interpersonal communication that shapes consumer satisfaction. Partial regression analysis results showed that openness, positive and supportive attitude have a significant effect on customer satisfaction, while empathy and equality have no effect on customer satisfaction. Simultaneously there was significant relation between interpersonal communication with customer satisfaction. Employees as the spearhead of a company should be able to communicate properly with consumers in order to increase of customer satisfaction.
\end{abstract}

Keywords: influence, communication, interpersonal, satisfaction, consumers 


\section{PENDAHULUAN}

Tingkat kesejahteraan masyarakat perkotaan yang semakin meningkat mendorong terjadinya pergeseran gaya hidup masyarakat perkotaan di Indonesia, termasuk dalam hal konsumsi kopi di kalangan generasi muda. Perubahan ini mendorong peluang bagi para pengusaha untuk membuka kedai kopi di kota-kota besar seperti di Bandung. Cafe dan Coffee Shop tumbuh cukup signifikan didorong oleh besarnya keingintahuan konsumen terhadap kopi racikan original dan juga minuman kopi olahan seperti espresso, latte, cappucino dan lainnya. Di Kota Bandung beragam kedai kopi mulai banyak bermunculan beberapa tahun belakangan ini (Tabel 1).

Tabel 1. Beberapa Kedai Kopi di Kota Bandung

\begin{tabular}{|c|c|c|}
\hline No & Kedai Kopi & Alamat \\
\hline 1 & Armor Kopi & $\begin{array}{l}\text { Taman Hutan Raya, Ir. H. } \\
\text { Djuanda, Cimenyan, Bandung }\end{array}$ \\
\hline 2 & Noah Barn & $\begin{array}{l}\text { Jalan Dayang Sumbi No. 2, } \\
\text { Bandung, Jawa Barat }\end{array}$ \\
\hline 3 & Blue Doors & $\begin{array}{l}\text { J1. Gandapura No.61, Bandung, } \\
\text { Jawa Barat }\end{array}$ \\
\hline 4 & $\begin{array}{l}\text { Kedai Kopi } \\
\text { Bara }\end{array}$ & $\begin{array}{l}\text { Jl. Cibadak No. } 237 \text { Bandung, } \\
\text { Jawa Barat }\end{array}$ \\
\hline 5 & $\begin{array}{l}\text { Jackrunner } \\
\text { Kopi }\end{array}$ & $\begin{array}{l}\text { Jl. Ciumbuleit No. } 42 \text { A, } \\
\text { Bandung, Jawa Barat }\end{array}$ \\
\hline 6 & $\begin{array}{l}\text { Morning } \\
\text { Glory }\end{array}$ & $\begin{array}{l}\text { Setra Sari Mall Kav C2 no } 31 \text {, Jln } \\
\text { Surya Sumantri, Bandung, Jawa } \\
\text { Barat }\end{array}$ \\
\hline 7 & $\begin{array}{l}\text { Two Hands } \\
\text { Full }\end{array}$ & $\begin{array}{l}\text { Sukajadi 206, Bandung, Jawa } \\
\text { Barat }\end{array}$ \\
\hline 8 & Dreezel & $\begin{array}{l}\text { Jalan Cisangkuy no 56, Bandung, } \\
\text { Jawa Barat }\end{array}$ \\
\hline
\end{tabular}

Data diatas merupakan beberapa kedai kopi lokal di Kota Bandung yang menyediakan atau menyajikan kopi dalam bentuk single origin atau kopi racikan original. Bagi sebagian kalangan, tujuan pergi ke sebuah kedai kopi bukan hanya untuk menikmati secangkir kopi, tetapi juga untuk berinteraksi dengan kerabat, mengerjakan tugas ataupun sekedar mengisi waktu luang. Peluang ini dilirik oleh kedai kopi khususnya yang ada di Kota Bandung dengan menawarkan beragam fasilitas yang membuat konsumen merasa nyaman untuk datang dan mengkonsumsi kopi di kedai mereka.

Setiap perusahaan, dalam hal ini kedai kopi tentunya ingin memenangkan persaingan bisnis dan mempertahankan konsumen agar tidak berpaling ke para pesaingnya. Salah satu upaya yang dapat dilakukan untuk merebut hati konsumen adalah dengan menciptakan kepuasan konsumen dengan membuat sistem pelayanan yang baik. Kotler (2000) mengatakan bahwa kepuasan konsumen merupakan perasaan konsumen setelah mereka membandingkan produk atau jasa yang mereka konsumsi dengan harapan terhadap produk atau jasa tersebut.

Salah satu faktor yang mempengaruhi kualitas pelayanan terhadap konsumen adalah yaitu komunikasi interpersonal yang terjalin antara karyawan sebagai ujung tombak perusahaan dan konsumen. Mulyana (2008) mendefinisikan komunikasi interpersonal sebagai komunikasi yang terjalin antar individu secara langsung sehingga memungkinkan setiap individu menangkap reaksi lawan bicaranya, baik secara verbal maupun nonverbal. Kotler (2000) mengatakan bahwa kepuasan konsumen akan lebih tinggi bila konsumen berinteraksi dengan karyawan yang memiliki keterampilan komunikasi yang baik. Panuju (2001) juga menyebutkan bahwa intreaksi akan terjalin lebih baik apabila diawali oleh proses komunikasi yang baik pula, sebab pesan atau informasi yang disampaikan oleh seseorang akan diterima dengan baik oleh penerima pesan.

Dari pemaparan di atas dapat disimpulkan bahwa kualitas dalam komunikasi interpersonal karyawan akan menentukan kepuasan konsumen. Pada kedai kopi, barista (karyawan yang meracik kopi) merupakan ujung tombak dalam proses interaksi dengan konsumen. Seorang barista harus memiliki pengalaman untuk menyajikan hasil penyeduhan kopi yang nikmat bagi konsumen.

Kedai Kopi Armor merupakan sebuah kedai kopi yang berlokasi di parkiran utama wisata THR (Taman Hutan Raya), Djuanda Dago Pakar, Bandung yang berdiri pada bulan Mei tahun 2015. Volume penjualan kopi di Kedai Kopi Armor terbilang masih berfluktuasi (Gambar 1). Fluktuasi penjualan di Kedai Kopi Armor terjadi akibat berbagai macam faktor, baik faktor eksternal seperti semakin ketatnya persaingan, maupun faktor internal yang terkait dengan kualitas pelayanan pada konsumen.

Untuk menghadapi persaingan pasar, Kedai Kopi Armor menambahkan value untuk meningkatkan kualitas pelayanan terhadap konsumen dengan menciptakan komunikasi 
sekaligus edukasi langsung oleh barista kepada konsumen, sehingga konsumen tidak hanya dapat menikmati kopi dengan harga terjangkau tetapi juga mendapatkan pengetahuan mengenai keunikan cara pembuatan kopi hingga macammacam teknik penyeduhan kopi. Untuk itu, barista di Kedai Kopi Armor dituntut tidak hanya memiliki keterampilan dalam meracik dan membuat minuman berbahan dasar kopi, namun juga keterampilan dalam menjalin komunikasi dengan konsumen.

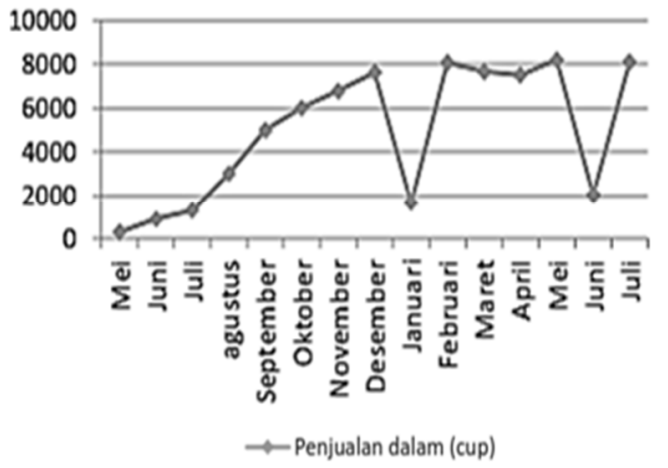

Gambar 1. Volume penjualan Kedai Kopi Armor Tahun 2015-2016

Sumber: Kedai Armor Kopi

Efektivitas dan kualitas komunikasi interpersonal yang terjalin antara barista dan konsumen dinilai dari lima dimensi yaitu "keterbukaan (openness), empati (empathy), sikap mendukung (supportiveness), sikap positif (positivenessi) dan kesetaraan (equality)" (De Vito, 2005)

Berdasarkan pemaparan di atas, penelitian ini bertujuan untuk mengetahui

1. Respon konsumen terhadap kualitas komunikasi interpersonal yang terjalin antara barista dengan konsumen di Kedai Kopi Armor.

2. Tingkat kepuasan konsumen di Kedai Kopi Armor.

3. Pengaruh kualitas komunikasi interpersonal terhadap kepuasaan pelanggan di Kedai Kopi Armor.

\section{METODE PENELITIAN}

Penelitian ini dilakukan di Kedai Kopi Armor Bandung. Kedai Kopi Armor dipilih sebagai lokasi penelitian dengan pertimbangan bahwa Kedai Kopi Armor merupakan kedai kopi yang menambahkan value yaitu edukasi langsung dari barista terhadap pelanggan dalam pelayanannya.
Penelitian ini merupakan penelitian kuantitatif dengan teknik penelitian survei. Yang menjadi variabel bebas dalam penelitian ini adalah kualitas komunikasi interpersonal yang terjalin antara barista dan konsumen di Kedai Kopi Armor, sedangkan yang menjadi variabel terikat adalah kepuasan konsumen di Kedai Kopi Armor. Jawaban responden terhadap variabel penelitian akan diukur menggunakan skala likert dengan skor 1-5.

Seluruh pertanyaan penelitian (23 item) dinyatakan valid dengan nilai $r$ pada masingmasing item $>0,3$ (Sugiyono, 2008).

Selanjutnya uji reliabilitas menunjukkan bahwa seluruh item pertanyaan memiliki nilai alpha cronbach $>0,7$, sehingga dapat dinyatakan item pertanyaan reliable.

Teknik Penentuan Responden

Populasi dalam penelitian ini adalah konsumen Kedai Kopi Armor. Besarnya populasi ditentukan berdasarkan rata-rata jumlah pelanggan yang datang setiap bulan, selama bulan Mei 2015 sampai dengan bulan Mei 2016, yaitu sebanyak 1568 konsumen. Berdasarkan jumlah populasi tersebut, ditentukan jumlah sampel berdasarkan rumus Slovin yaitu sebanyak 94 orang. Sampel diambil secara dengan teknik acak sederhana. Waktu penyebaran kuesioner di lakukan dengan cara proporsional dengan menetapkan sebaran tiap harinya hingga satu minggu antara jam $12.00-21.00$ WIB. Sebaran responden pada saat week end lebih banyak di banding week days di karenakan volume pengunjung lebih banyak pada saat week end dibanding week days. Berikut ini adalah sebaran jumlah responden yang akan diwawancarai selama satu minggu.

\begin{tabular}{cccc}
\hline Hari & $\begin{array}{c}\text { Responden } \\
\text { (Orang) }\end{array}$ & Hari & $\begin{array}{c}\text { Responden } \\
\text { (Orang) }\end{array}$ \\
\hline Senin & 10 & Jumat & 10 \\
Selasa & 10 & Sabtu & 22 \\
Rabu & 10 & Minggu & 22 \\
Kamis & 10 & Jumlah & $\mathbf{9 4}$ \\
\hline
\end{tabular}

\section{Rancangan Analisis Data dan Uji}

Hipotesis. Analisis deskriptif digunakan untuk menggambarkan respon konsumen dan tingkat kepuasan konsumen terhadap kualitas komunikasi interpersonal yang terjalin antara barista dan konsumen. Untuk menetapkan kriteria setiap variabel, dapat dilihat dari perbandingan antara skor actual dengan skor ideal.

Skor actual diperoleh dari hasil 
perhitungan seluruh jawaban responden sesuai bobot yang diberikan (1-5). Sedangkan skor ideal diperoleh dari prediksi bobot tertinggi dikalikan dengan jumlah pertanyaan dikalian dengan jumlah responden (Narimawati, 2007)

Kategori skor:

$$
\% \text { skor }=\frac{\text { skor aktual }}{\text { skor ideal }} \times 100 \%
$$

$$
\begin{array}{ll}
0 \%-20 \% & : \text { Sangat buruk } \\
21 \%-40 \% & : \text { Kurang baik } \\
41 \%-60 \% & : \text { Cukup baik } \\
61 \%-80 \% & : \text { Baik } \\
81 \%-100 \% & : \text { Sangat baik }
\end{array}
$$

Uji statistik melalui teknik analisis regresi berganda dilakukan untuk melihat pengaruh komunikasi interpersonal yang terjalin antara barista dan konsumen terhadap kepuasan konsumen, dengan persamaan regresi sebagai berikut

$$
\begin{aligned}
Y=a+b 1 X 1 & +b 2 X 2+b 3 X 3+b 4 X 4 \\
& +b 5 X 5+e
\end{aligned}
$$

Keterangan:

$\begin{array}{ll}\mathrm{Y} & : \text { Kepuasan Pelanggan } \\ \boldsymbol{a} & \text { : Konstanta } \\ \mathrm{X}_{1} & \text { : Keterbukaan (Openness) } \\ \mathrm{X}_{2} & \text { : Empati (Empathy) } \\ \mathrm{X}_{3} & \text { : Sikap Mendukung (Supportiveness) } \\ \mathrm{X}_{4} & \text { : Sikap positif (Positiveness) } \\ \mathrm{X}_{5} & \text { : Kesetaraan (Equality) } \\ b & \text { : Koefisien Regresi }\end{array}$

\section{A. Uji Parsial (Uji t)}

Uji parsial dilakukan untuk menguji kemaknaan koefisien parsial atau masingmasing variabel bebas terhadap variabel terikat. Dalam uji parsial digunakan distribusi t. Apabila t hitung $\leq \alpha(5 \%)$, maka Ho ditolak dan Ha diterima, artinya variabel bebas (X) berpengaruh terhadap variabel terikat (Y), dan sebaliknya

\section{B. Uji Simultan (Uji F)}

Uji F dilakukan untuk mengetahui apakan semua variabel bebas secara bersamasama menunjukkan pengaruh terhadap variabel terikat. Hipotesis untuk uji $\mathrm{F}$, apabila probabilitas $<$ taraf signifikan (5\%), maka Ho ditolak dan Ha diterima, yang artinya terdapat pengaruh antara variabel bebas $\left(\mathrm{X}_{1}, \mathrm{X}_{2}, \mathrm{X}_{3}, \mathrm{X}_{4}\right.$ dan $X_{5}$ ) secara bersama sama terhadap variabel terikat (Y); dan sebaliknya.

\section{HASIL DAN PEMBAHASAN \\ Karakteristik Responden}

Jenis Kelamin. Lebih dari separuh

responden yang datang ke Kedai Kopi Armor berjenis kelamin laki-laki (63,83\%). Hasil kajian Coffee Association of Canada (2015) juga menunjukkan hal yang serupa. Hal ini dikarenakan laki-laki mempunyai kebiasaan meminum kopi lebih banyak dibanding perempuan.

Usia. Konsumen kopi di Kedai Kopi Armor mayoritas termasuk dalam kategori usia remaja akhir (17-25 tahun) yaitu sebanyak $95 \%$, diikuti dengan konsumen dengan kategori usia dewasa awal (26-35 tahun) yaitu sebesar 5\%. Menurut Zen (2014), tren berkumpul di warung kopi, khususnya di kalangan kaum muda Asia tidak diragukan lagi dan lazim di seluruh wilayah. Konsumen Kedai Kopi Armor dengan usia 17 hingga 28 tahun masih dapat digolongkan sebagai kaum muda yang mengikuti tren untuk mengkonsumsi kopi dan berkumpul di kedai kopi (Herlyana, 2012).

Tingkat Pendidikan. Engel, et.al (1994) mengatakan perilaku pembelian dapat ditentukan oleh perbedaan tingkat pendidikan. Tingkat pendidikan berpengaruh dalam menentukan tingkat pengetahuan dan sikap seseorang yang pada akhirnya berperan penting dalam membentuk pilihan produk. Lebih dari separuh responden $(59,6 \%)$ di Kedai Kopi Armor berpendidikan SMA. Jika dikaitkan dengan usia responden yang sebagian besar kaum muda, kalangan kaum muda mengikuti tren terhadap keunikan kopi maka banyak dari kaum muda yang ingin lebih mengetahui pengetahuan tentang kopi dan menyukai kopi (Herlyana, 2012).

Jenis Pekerjaan. Sebagian besar responden $(75,6 \%)$ merupakan pelajar/ mahasiswa, dan sisanya berprofesi sebagai karyawan ataupun berprofesi sebagai wiraswasta. Sebagian besar responden berkunjung ke Kedai Kopi Armor atas dasar ingin berkumpul dengan teman di kedai kopi ataupun bertemu relasi bisnis. Herlyana (2012) menyatakan kaum muda mengikuti tren untuk mengkonsumsi kopi serta berkumpul di warung-warung kopi sebagai ajang pergaulan serta relasi sosial.

\section{Respon Konsumen Terhadap} Komunikasi Interpersonal. Respon konsumen terhadap komunikasi interpersonal yang terjalin antara barista dan konsumen diukur melalui 13 item pertanyaan. Kualitas komunikasi interpersonal diukur melalui lima dimensi, yaitu "dimensi keterbukaan, empati, sikap mendukung, sikap positif dan 
kesetaraan."

A. Dimensi Keterbukaan

De Vito (2005) menjabarkan bahwa

dimensi keterbukaan menggambarkan dua aspek dalam komunikasi interpersonal.

Pertama, seseorang harus bersikap terbuka pada orang lain yang berinteraksi dengan mereka, dalam artian memiliki keinginan untuk membuka diri pada hal-hal baru ataupun yang bersifat umum, sehingga orang lain akan mengetahui pikiran, pendapat dan gagasan kita. Kedua, adalah bersikap terus terang terhadap segala sesuatu yang

dikomunikasikan.

Hasil kriteria skor tanggapan responden menunjukkan bahwa keterbukaan barista dalam berkomunikasi dengan konsumen tergolong baik, dengan skor 77,5 \% (Tabel 2). Responden menilai barista jujur dalam menjelaskan rasa kopi kepada konsumen, sehingga konsumen dapat mengetahui kelebihan dan kekurangan dari berbagai jenis kopi yang ada di Kedai Kopi Armor. Dengan adanya penjelasan dari barista tentang produk, konsumen dapat mengetahui produk yang cocok dengan keinginan mereka, contohnya ketika seorang konsumen menginginkan kopi yang pahit dan kental maka barista akan memberi refrensi jenis kopi yang pahit dan penggunaan alat yang pas untuk jenis kopi tersebut. Responden juga menilai bahwa barista dan juga karyawan lain di Kedai Kopi Armor bersikap terbuka terhadap kritik dan saran dari pengunjung.

B. Dimensi Empati

Menurut De Vito (2005) empati merupakan sikap seseorang yang menunjukkan kemampuan untuk memahami apa yang sedang dirasakan atau dialami oleh orang lain pada saat tertentu. Untuk dapat berempati diperlukan kepekaan baik peka terhadap perasaan orang lain ataupun pesan verbal lainnya.

Hasil kriteria skor tanggapan responden pada Tabel 2 menunjukkan bahwa empati karyawan Kedai kopi Armor Bandung, secara total berada dalam kategori baik dengan skor 73,6\%. Karyawan, khususnya barista dapat memahami keinginan dan kebutuhan konsumen, contohnya ketika ada konsumen yang tidak menyukai kopi rasa original, karyawan berinisiatif menawarkan kopi susu atau contohnya kopi tipe liberica dicampur dengan susu, sehingga rasa kopi tidak terlalu kental dan tidak pahit. Dalam memenuhi kebutuhan konsumen, karyawan dinilai tanggap menyediakan kebutuhan konsumen, contohnya konsumen meminta gula atau asbak, karyawan cukup tanggap untuk melayani kebutuhan konsumen tersebut. Namun sebagian kecil konsumen menilai penyediaan kebutuhan untuk konsumen tidak merata, contohnya penyediaan asbak dan stop contact tidak tersedia di seluruh meja. Menurut pengelola Kedai Kopi Armor, konsep yang ditonjolkan dalam kedai kopi tersebut adalah suasana yang alami dengan lokasi di taman hutan raya yang kental dengan alam, sehingga pengelola sengaja tidak menyediakan beberapa fasilitas, seperti stop kontak.

C. Dimensi Sikap Mendukung Menurut De Vito (2005), sikap mendukung merupakan sikap yang mengurang sikap defensif. Sikap ini akan mempengaruhi hubungan interpersonal yang terjadi. Komunikasi yang efektif dapat berlangsung dalam suasana yang mendukung.

Hasil kriteria skor tanggapan responden pada Tabel 2 menunjukkan bahwa sikap mendukunng karyawan Kedai Kopi Armor, secara total berada dalam kategori baik dengan skor $77 \%$. Cara komunikasi karyawan terhadap konsumen di Kedai Kopi Armor dinilai oleh sebagian besar responden sudah tepat.

Responden merasa nyaman ketika berkomunikasi dan responden juga merasa tidak ada jarak dalam komunikasi. Jika konsumen merasa ada kekurangan akan produk yang disajikan atau fasilitas yang diberikan, konsumen dapat mengemukakan kritiknya kepada karyawan, hal tersebut akan ditanggapi dengan baik dan terbuka oleh karyawan. Selanjutnya cara penjelasan (edukasi) barista dilakukan dengan jelas dan ramah, sehingga konsumen merasa nyaman dan mudah untuk memahami apa yang disampaikan oleh barista.

D. Dimensi Sikap Positif

De Vito (2005) mengatakan komunikasi interpersonal dapat terjalin dengan baik apabila seseorang memiliki dan menunjukkan sikap yang positif terhadap diri mereka sendiri dan juga orang lain dalam berbagai situasi komunikasi. Hasil kriteria skor tanggapan responden menunjukkan bahwa sikap positif karyawan Kedai kopi Armor Bandung, secara total berada dalam keadaan baik dengan skor 81,1\% (Tabel 2). Sikap dan cara karyawan terutama barista dalam melayani konsumen dinilai ramah. Barista bersikap positif terhadap keinginan konsumen dalam memilih produk, 
contohnya barista akan memberikan masukan masukan terhadap konsumen dalam pemilihan jenis produk yang mengacu pada kesesuaian produk yang diinginkan konsumen.

E. Dimensi Kesetaraan

Komunikasi interpersonal akan terjalin dengan lebih efektif apabila para pelaku komunikasi mempunyai nilai, sikap, perilaku, pandangan dan pengalaman yang sama.

(DeVito, 2005). Sikap kesetaraan karyawan Kedai Kopi Armor, berada dalam kategori baik dengan skor 77,5\% (Tabel 2). Hal ini mengindikasikan bahwa karyawan tidak membeda-bedakan konsumen dalam melayani konsumen. Semua akan dilayani dengan baik dan adil. Barista juga akan mengedukasi konsumen yang ingin mengetahui proses penyajian kopi, baik konsumen yang menyukai kopi ataupun tidak.

Berdasarkan hasil perhitungan, rata-rata skor total untuk komunikasi interpersonal adalah sebesar $77,09 \%$ yang terletak antara rentang 61 - $80 \%$ yang terdapat pada kriteria baik. Hal ini menunjukkan konsumen merespon positif mengenai kualitas pelayanan yang dinilai dari kualitas komunikasi interpersonal yang terjalin antara karyawan, khususnya barista dengan konsumen kedai

Tabel 2 Respon Konsumen terhadap Komunikasi Interpersonal di Kedai Kopi Armor

\begin{tabular}{|c|c|c|c|c|}
\hline Pernyataan & $\begin{array}{c}\text { Skor } \\
\text { Aktual }\end{array}$ & $\begin{array}{l}\text { Skor } \\
\text { Ideal }\end{array}$ & $\begin{array}{c}\% \\
\text { Skor }\end{array}$ & Kriteria \\
\hline \multicolumn{5}{|l|}{ Dimensi Keterbukaan } \\
\hline 1. Barista jujur dalam melayani konsumen & 378 & 470 & 80.4 & Sangat Baik \\
\hline $\begin{array}{l}\text { 2. Barista memberikan penjelasan kepada konsumen dalam } \\
\text { memilih menu }\end{array}$ & 360 & 470 & 76.6 & Baik \\
\hline 3. Barista bersedia menerima kritik dan saran & 355 & 470 & 75.5 & Baik \\
\hline Total Dimensi Keterbukaan & 1093 & 1410 & 77,5 & Baik \\
\hline \multicolumn{5}{|l|}{ Dimensi Empati } \\
\hline $\begin{array}{l}\text { 4. Karyawan (barista) memahami keinginan dan kebutuhan } \\
\text { pelanggan }\end{array}$ & 346 & 470 & 73.6 & Baik \\
\hline $\begin{array}{l}\text { 5. Karyawan tanggap dalam memenuhi kebutuhan dan } \\
\text { keinginan pelanggan }\end{array}$ & 365 & 470 & 77.6 & Baik \\
\hline $\begin{array}{l}\text { 6. Karyawan menyediakan segala sesuatu yang diperlukan } \\
\text { pelanggan (misalnya asbak, tissue, colokan listrik, dll) }\end{array}$ & 327 & 470 & 69.6 & Baik \\
\hline Total Dimensi Empati & 1038 & 1410 & 73,6 & Baik \\
\hline \multicolumn{5}{|l|}{ Dimensi Sikap Mendukung } \\
\hline $\begin{array}{l}\text { 7. Sikap dan cara barista berkomunikasi membuat konsumen } \\
\text { nyaman }\end{array}$ & 381 & 470 & 81 & Baik \\
\hline $\begin{array}{l}\text { 8. Barista mendengarkan keluhan yang disampaikan dengan } \\
\text { seksama }\end{array}$ & 383 & 470 & 81 & Baik \\
\hline $\begin{array}{l}\text { 9. Barista menerima kritik dan saran yang disampaikan } \\
\text { konsumen dengan sikap terbuka }\end{array}$ & 345 & 470 & 73.4 & Baik \\
\hline 10. Barista tidak segan meberikan edukasi kepada konsumen & 369 & 470 & 78.5 & Baik \\
\hline Total Dimensi Sikap Mendukung & 1448 & 1880 & 77,0 & Baik \\
\hline \multicolumn{5}{|l|}{ Dimensi Sikap Positif } \\
\hline 11. Karyawan bersikap ramah kepada konsumen & 371 & 470 & 78.9 & Baik \\
\hline $\begin{array}{l}\text { 12. Karyawan memberikan pendapat positif kepada pilihan } \\
\text { konsumen }\end{array}$ & 361 & 470 & 76.8 & Baik \\
\hline Total Dimensi Sikap Positif & 762 & 940 & $\mathbf{8 1 , 1}$ & Baik \\
\hline \multicolumn{5}{|l|}{ Dimensi Kesetaraan } \\
\hline 13. Karyawan tidak membeda-bedakan konsumen & 369 & 470 & 78.5 & Baik \\
\hline Total & 4710 & 6110 & 77.09 & Baik \\
\hline
\end{tabular}


Tabel 3. Kepuasan Responden terhadap Kualitas Pelayanan di Kedai Kopi Armor

\begin{tabular}{|c|c|c|c|c|}
\hline Pernyataan & $\begin{array}{c}\text { Skor } \\
\text { Aktual }\end{array}$ & $\begin{array}{l}\text { Skor } \\
\text { Ideal }\end{array}$ & \% Skor & Kriteria \\
\hline 1. Kemudahan konsumen memahami penjelasan barista & 360 & 470 & 76.6 & Sangat puas \\
\hline 2. Kemudahan konsumen berkomunikasi dengan barista & 363 & 470 & 77.2 & Puas \\
\hline $\begin{array}{l}\text { 3. Alat yang digunakan oleh karyawan dalam penyajian kopi } \\
\text { sudah memadai }\end{array}$ & 379 & 470 & 80.6 & Puas \\
\hline 4. Penampilan karyawan cukup sopan dan menarik & 353 & 470 & 75.1 & Puas \\
\hline 5. Konsumen mendapatkan produk sesuai yang di inginkan & 379 & 470 & 80.6 & Puas \\
\hline 6. Konsumen mendapatkan penyajian produk dengan cepat & 336 & 470 & 71.4 & Puas \\
\hline 7. Konsumen dilayani dengan tanggap & 366 & 470 & 77.8 & Puas \\
\hline 8. Konsumen dilayani sesuai dengan harapan & 365 & 470 & 77.6 & Puas \\
\hline 9. Konsumen dilayani dengan sopan & 374 & 470 & 79.5 & Puas \\
\hline 10. Konsumen dilayani dengan ramah & 383 & 470 & 81.4 & Puas \\
\hline Total & 3658 & 4700 & $\mathbf{7 7 . 8}$ & Puas \\
\hline
\end{tabular}

kopi Armor. Aretha (2015) juga menyimpulkan bahwa komunikasi interpersonal karyawan di kedai kopi Espreso Yogyakarta berlangsung dengan baik karena adanya tambahan value edukasi dari seorang barista terhadap konsumen tanpa membedakan konsumen.

Kepuasan Responden terhadap Kualitas Pelayanan di Kedai Kopi Armor. Kepuasan responden diukur melalui sepuluh item pertanyaan untuk menggambarkan kualitas pelayanan.

Pada Tabel 3 dapat dilihat bahwa secara umum responden merasa puas terhadap kualitas pelayanan di Kedai Kopi Armor. Responden menilai pelayanan yang diberikan di Kedai Kopi Armor sudah cukup baik, namun bererapa responden menilai ada sedikit kekurangan dalam penyajian kopi yang memerlukan waktu yang cukup lama dikarenakan proses penyajiannya dengan cara manual.

Dalam hal komunikasi dengan barista, responden menilai komunikasi tergolong baik. Konsumen dapat dengan mudah memahami penjelasan dari barista tentang edukasi keunikan kopi atau penyajiannya. Barista akan memberikan penjelasan (mengedukasi) konsumen, dengan menganalisa pengetahuan konsumen terlebih dahulu mengenai kopi, apakah konsumen sudah memiliki pengetahuan tetntang kopi original atau belum. Dengan begitu barista bisa menentukan cara mengedukasi konsumen seperti penjelasan yang lebih mendalam atau secara ringan.

Pelayanan yang diberikan kepada konsumen, secara umum berada dalam kategori baik dengan skor 77.7\% (Tabel 3). Hal ini mengindikasikan bahwa konsumen sudah cukup merasakan pelayanan yang tanggap dan sesuai dengan harapan.
Contohnya konsumen memilih cara pengolahan kopi dengan menggunakan alat flat bottom dengan biji toraja, maka barista akan menyajikan kopi sesuai dengan pilihan pelanggan dengan keterampilan dari barista, maka beans kopi toraja dengan alat flat bottom dibuat hingga mendapatkan rasa sesuai dengan yang diharapkan.

Responden juga berpendapat bahwa pelayanan yang diberikan oleh karyawan di Kedai Kopi Armor sangat ramah dan sopan terhadap pelanggan dengan mengedepankan etika dalam melayani konsumen. Kemudian skill atau kemampuan barista dalam meracik kopi di nilai oleh konsumen sudah baik.

Pengaruh Komunikasi Interpersonal terhadap Kepuasan Pelanggan di Kedai Kopi Armor. Pendugaan model kepuasan pelanggan diduga dengan metoda Ordinary Least Squares (OLS), sebelum model digunakan maka dilakukan pengujian menurut kriteria statistik dan ekonometrik. Pengujian ekonometrik meliputi asumsi yang digunakan, pengujian ekonomi meliputi tanda dan besaran, sedangkan pengujian statistk meliputi uji statistik yang digunakan

\section{Pengujian Asumsi}

Uji Asumsi Normalitas. Uji normalitas dilakukan untuk mendeteksi apakah data yang digunakan berdistribusi normal atau tidak. Hasil uji normalitas menunjukkan data dapat dikatakan memenuhi persyaratan untuk analisis regresi linear berganda.

Uji Asumsi Multikolinearitas. Uji kolinearitas dilakukan untuk mengetahui apakah ada collinearity atau tidak diantara variabel bebas. Dari hasil perhitungan diketahui bahwa tidak terjadi multikolinieritas dalam model garis regresi berganda.

Uji Asumsi Heteroskedasitas. Hasil 
analisis menunjukkan data bersifat

homoskedastisitas/ tidak terjadi

heteroskedastisitas dan memenuhi persyaratan

untuk analisa regresi.

\section{Hasil Dugaan Model Kepuasan Pelanggan}

A. Koefisien Korelasi dan Koefisien Determinasi

Hasil analisis data dengan bantuan

software SPSS versi 23.0 diperoleh koefisien

korelasi berganda dan koefisien determinasi

berdasarkan output nilai koefisien korelasi

berganda antara keterbukaan $\left(\mathrm{X}_{1}\right)$, empati $\left(\mathrm{X}_{2}\right)$,

sikap mendukung $\left(\mathrm{X}_{3}\right)$, sikap positif $\left(\mathrm{X}_{4}\right)$ dan

kesetaraan $\left(\mathrm{X}_{5}\right)$ berpengaruh secara simultan

terhadap kepuasan pelanggan $(\mathrm{Y})$. Nilai $\mathrm{r}=0.803$

menunjukkan hubungan yang sangat kuat.

Nilai koefisien determinasi adalah $64,5 \%$ yang berarti kepuasan pelanggan dapat dijelaskan sebesar $64,5 \%$ oleh keragaan variabel keterbukaan $\left(\mathrm{X}_{1}\right)$, empati $\left(\mathrm{X}_{2}\right)$, sikap mendukung $\left(\mathrm{X}_{3}\right)$, sikap positif $\left(\mathrm{X}_{4}\right)$ dan kesetaraan $\left(\mathrm{X}_{5}\right)$ sedangkan sisanya $35.5 \%$ dipengaruhi oleh faktor lain yang tidak diteliti. Hasil tersebut menunjukkan model kepuasan pelanggan dinyatakan cukup baik.

B. Pengujian hipotesis Secara Simultan (Uji F)

Uji F digunakan untuk melihat pengaruh variabel-variabel bebas secara bersama-sama atas suatu variabel terikat. Hasil pengujian hipotesis secara stimultan diperoleh nilai $\mathrm{F}_{\text {hitung }}$ sebesar 31,909. Sedangkan harga kritis nilai $\mathrm{F}_{\text {tabel }}$ dengan derajat bebas pembilang 5 dan penyebut 88 pada $\alpha(0,05)$ sebesar 2,32 . Dengan demikian $F_{\text {hitung }}>F_{\text {tabel, }}$, sehingga Ho ditolak dan Ha diterima. Hal ini menunjukkan bahwa keterbukaan $\left(\mathrm{X}_{1}\right)$, empati $\left(\mathrm{X}_{2}\right)$, sikap mendukung $\left(\mathrm{X}_{3}\right)$, sikap positif $\left(\mathrm{X}_{4}\right)$ dan kesetaraan $\left(\mathrm{X}_{5}\right)$ berpengaruh secara simultan terhadap kepuasan pelanggan $(\mathrm{Y})$.

Hasil penelitian menunjukan bahwa dimensi komunikasi interpersonal berpengaruh signifikan terhadap kepuasan pelanggan melalui dimensi kualitas pelayanan. Hal ini mengindikasikan bahwa kualitas pelayanan di Kedai Kopi Armor sudah berlangsung baik, dan komunikasi yang terjadi sudah cukup baik mengingat barista menerapkan edukasi terhadap konsumen. Penelitian sebelumnya yang dilakukan oleh Aretha (2014) juga menunjukan bahwa komunikasi interpersonal berpengaruh signifikan terhadap kepuasan konsumen.

C. Hasil Uji Parsial

Berdasarkan analisis data baik untuk variabel bebas $(\mathrm{X})$ dan variabel terikat $(\mathrm{Y})$, diperoleh persamaan regresi sebagai berikut:

$\mathrm{Y}=1,142+0,680 \mathrm{X}_{1}+0,471 \mathrm{X}_{2}+0,739$

$$
\mathrm{X}_{3}+0,854 \mathrm{X}_{4}+0,778 \mathrm{X}_{5}+\mathrm{e}
$$

Keterangan:

Y : Kepuasan Pelanggan

a : Konstanta

$\mathrm{X}_{1} \quad$ : Keterbukaan (Openness)

$\mathrm{X}_{2} \quad$ : Empati (Empathy)

$\mathrm{X}_{3}$ : Sikap Mendukung (Supportiveness)

$\mathrm{X}_{4} \quad$ : Sikap positif (Positiveness)

$\mathrm{X}_{5} \quad$ : Kesetaraan (Equality)

$b \quad$ : Koefisien Regresi

Persamaan regresi tersebut dapat dijelaskan sebagai berikut:

a. Koefesien dimensi Keterbukaan $\left(\mathrm{X}_{1}\right)$ adalah $(0,680)$ bertanda positif dan signifikan terhadap kepuasan konsumen (Y) dengan nilai $\mathrm{t}_{\text {hitung }}$ sebesar 2,556 ( $\mathrm{t}_{\text {tabel }}$ $=1,98729)$, ini berarti semakin terbuka barista terhadap konsumen maka konsumen semakin puas, sebaliknya jika variabel keterbukaan mengalami penurunan maka kepuasan pelanggan di Kedai Kopi Armor juga mengalami penurunan. Hal tersebut dikarenakan kurangnya sikap terbuka dapat menyebabkan mis presepsi. Sikap terbuka ditandai dengan adanya kejujuran merespon segala stimuli komunikasi. Dengan demikian konsumen akan mengetahui pendapat, pikiran, gagasan dari barista atau sebaliknya. Keterbukaan menjadi sikap yang berpengaruh terhadap kepuasan pelanggan.

b. Koefesien dimensi Empati $\left(\mathrm{X}_{2}\right)$ adalah (0, 471) bertanda positif namun tidak signifikan terhadap kepuasaan konsumen $(Y)$, hal ini menunjukkan bahwa karyawan dapat memahami keinginan dan kebutuhan sesuai konsumen, misalnya terhadap konsumen yang tidak menyukai kopi rasa original, karyawan berinisiatif menawarkan kopi yang lebih soft. Namun kualitas tersebut dinilai merupakan hal yang biasa dan sudah menjadi layanan standar di berbagai kedai kopi, sehingga dimensi empati tidak mempengaruhi kepuasan konsumen ketika berkunjung ke Kedai Kopi Armor.

c. Koefesien dimensi Sikap Mendukung $\left(\mathrm{X}_{3}\right)$ adalah $(0,739)$ bertanda positif dan berpengaruh signifikan terhadap kepuasan konsumen (Y). Artinya semakin baik sikap mendukung yang ditunjukkan oleh karyawan, maka konsumen akan semakin puas. Segala kritik, saran dan masukkan ditanggapi dengan baik oleh karyawan. 
Cara penjelasan (edukasi) barista

dilakukan dengan jelas dan ramah, sehingga konsumen merasa nyaman dan mudah dimengerti

d. Koefesien dimensi Sikap Positif $\left(\mathrm{X}_{4}\right)$ adalah $(0,854)$ bertanda positif dan berpengaruh signifikan terhadap kepuasan konsumen (Y), ini berarti semakin baik sikap positif karyawan dalam berkomunikasi dengan konsumen, maka kepuasan konsumen akan semakin meningkat. Sikap positif barista akan membantu konsumen dalam memilih produk sesuai dengan keinginan mereka, sehingga konsumen merasa lebih dihargai.

e. Koefesien dimensi Kesetaraan $\left(\mathrm{X}_{5}\right)$ adalah $(0,778)$ bertanda positif namun tidak signifikan terhadap kepuasan konsumen (Y), Kesetaraan dilakukan karyawan dalam melihat konsumennya. Karyawan tidak membeda-bedakan konsumennya dari rentang umur, gender dan pengalamannya. Semua konsumen dilayani dan diberi edukasi dengan baik dan adil. Konsumen kurang merasakan dimensi keseteraraan dapat meningkatkan kepuasan konsumen ketika berkunjung ke Kedai Kopi Armor.

\section{KESIMPULAN DAN SARAN}

Komunikasi interpersonal yang terjalin antara karyawan dengan konsumen sudah tergolong baik. Namun skor terendah di dapat pada indikator empati, walaupun skor tersebut masih tergolong baik, tetapi terdapat kekurangan terhadap penyediaan fasilitas untuk konsumen seperti stop contact listrik, wifi. Hal tersebut di karenakan Kedai Kopi Armor ingin menjadikan cafenya sebagai sarana untuk berkumpul dan melakukan saling interaksi secara langsung, sehingga pemakaian wifi dianggap menghambat komunikasi.

Kepuasan pelanggan melalui kualitas pelayanan sudah tergolong baik. Namun skor terendah di dapat pada pada indikator kepercayaan mengenai pernyataan konsumen tentang kecepatan penyajian. Penyajian kopi di Kedai Kopi Armor tergolong tidak cepat, di karenakan proses dalam penyajian hanya menggunakan alat-alat manual dan cara penyajian yang unik, sehingga untuk mendapatkan cita rasa yang sesuai membutuhkan waktu.

Dari hasil pengujian secara statistik, diketahui bahwa sikap mendukung, sikap positif dan sikap terbuka akan meningkatkan kepuasan pelanggan, karena konsumen bisa mendapatkan dan mengetahui produk sesuai dengan keinginan dengan dibantu oleh penjelasan dari barista.

Variabel empati dan kesetaraan tidak menunjukkan hasil yang signifikan terhadap kepuasan pelanggan. Hal ini diduga karena variabel empati dan kesetaraan tidak berpengaruh langsung dalam meningkatkan kepuasan pelanggan tetapi melalui variabelvariabel lainnya yang tidak diteliti.

Pihak manajemen Kedai Kopi Armor diharapkan dapat membekali karyawan pengetahuan dan keterampilan dalam hal pelayanan konsumen agar menjadi lebih baik lagi, karena dengan pelayanan yang semakin baik, kepuasan kunsumen dapat meningkat.

Kedai Kopi Armor hanya menggunakan alat-alat manual untuk meracik kopi, hal ini mengakibatkan terkadang konsumen harus menunggu lama untuk dapat mengkonsumsi secangkir kopi. Untuk mengefisiensikan waktu diharapkan manajemen Kedai Kopi Armor dapat menambahkan barista agar waktu dalam penyajian kopi dapat dilakukan lebih efisien dengan tidak mengurangi karakter natural dari Kedai Kopi Armor yang diracik dengan menggunakan alat-alat manual.

Kedai Kopi Armor dapat menambahkan beberapa fasilitas di tiap meja seperti tisu dan asbak. Walaupun wifi tidak disediakan karena alasan dapat menghambat interaksi sosial secara langsung dengan orang sekitarnya, Kedai kopi armor bisa menyediakan fasilitas seperti misalnya game tradisional untuk dapat dimainkan konsumen bersama-sama sehingga dapat menjalin keseruan konsumen sambil menikmati kopi di Kedai Kopi Armor. Hal tersebut diharapkan dapat meningkatkan kepuasan pelanggan.

\section{DAFTAR PUSTAKA}

Aretha, Natasha. 2014. Pengaruh Kualitas Komunikasi Interpersonal Terhadap Tingkat Loyalitas Pelanggan. http://ejournal.uajy.ac.id/ Yogyakarta: Universitas Atmajaya.

Armstrong dan Kotler. 1999. Prinsip- Prinsip Pemasaran. Jakarta: Erlangga

De Vito, Joseph H. 2005. The Interpersonal Communication. Book. Person Education.Inc

Engel, James F; Roger, D Blackwell; Paul, W. Miniad. 1995. Perilaku Konsumen, edisi ke 6 jilid kedua. Jakarta : Binarupa Aksara 
Harun Al rasyid .1996. Teknik Penarikan Sampel Dan Penyusunan Skala. Bandung : Program Pasca Sarjana, Universitas Padjadjaran.

Irawan .2003. Pendekatan Mutu dan Kepuasan Pelanggan dalam Pelayanan Kesehatan, Program Pasca Sarjana UNHAS

Kotler, Phillip ,2000. Manajemen Pemasaran. Jakarta : Prenhallindo

Mulyana, Deddy. 2005. Ilmu Komunikasi : Suatu Pengantar. Bandung : Remaja Rosdakarya

Narimawati, Umi. 2007. Riset Manajemen Sumberdaya Manusia. Jakarta : Agung Media.
Panuju, Redi. 2001. Perilaku Organisasi dan Komunikasi Suatu Pengantar. Jakarta : Gramedia Pustaka Utama

Primadevi, Lucia Wardani. 2012. Hubungan Kualitas Komunikasi Interpersonal Dengan Kepuasan Relasi Antara Customer Service Officer dan Pelanggan Mal Malioboro Yogyakarta. Yogyakarta : Universitas Atma Jaya.

Sugiyono. 2008. Metode Penelitian Pendidikan Pendekatan Kuantitatif, Kualitatif, dan $R$ $\& D$. Bandung : Alfabeta

Sugiyono. 2009. Metode Penelitian Bisnis. Bandung : Alfabeta 